\title{
Podoby Salome v díle Jaroslava Vrchlického
}

\author{
Soňa Šinclová
}

\section{ABSTRACT \\ The Imagery of Salome in Vrchlický's Work}

In the 19th century, the image of Salome was transformed by significant changes that reflect contemporary social phenomena and changes in national literatures. Among the artists who depicted Salome in this period, whether in the context of Bible story or in the end of the century form of the femme fatale, Jaroslav Vrchlický forms an exception. In his work, it is possible to find several different images of Salome, which not only correspond to his artistic development, but at the same time they reflect his views foreign literatures, especially those from Western Europe, from which he was translating.

The aim of the study is not only to describe the images of Salome in Vrchlickýs work, but also to incorporate the selected scenes or allusions to the story of John the Baptist's beheading into the context of the author's work and, last but not least, track down possible sources of inspiration that reflected themselves in the imagery of Salome, in Vrchlickýs translation work.

\section{KEYWORDS}

Czech literature, Jaroslav Vrchlický, Salome, John the Baptist, literature in translation, poetry.

\section{KLÍčOVÁ SLOVA}

Česká literatura, Jaroslav Vrchlický, Salome, Jan Křtitel, literatura v překladu, poezie.

Rok po smrti Jaroslava Vrchlického vydal F. X. Šalda knihu Duše a dílo (1913), ve které hodnotil díla vybraných českých i zahraničních literátů a myslitelů. Mezi nimi věnoval pozornost i Jaroslavu Vrchlickému, u něhož na závěr vyzvedl jeho dobový význam pro českou literaturu: „Vrchlický jest největší posud revoluce v českém kulturním světě. Do národa pochmurného a meditativního, 
žijícího posud smyslem spíš vnitřním než smysly vnějšími, i v rozkoši melancholického a teskného, vtrhuje Vrchlickým poesie jásavé fanfáry, optimistická a skutečnostná, plna hladu a žízně po všech darech země a světa, prudce a horce zmocňující se života ve všech jeho tvarech, poesie výbojná a nerozpačitá, která nalézá na každou záhadu ihned odpověd, jako rozvádí rychle každou dissonanci $\mathrm{v}$ harmonii, teplá $\mathrm{v}$ barvě, smyslná ve formě, útočná $\mathrm{v}$ intonaci“ (ŠALDA 1913: 143).

Jaroslav Vrchlický obohatil českou literaturu nejen svou původní tvorbou (čítající desítky básnických sbírek a řadu próz a dramat), ale i rozsáhlou překladatelskou činností. Hlavní pozornost přitom Vrchlický směřoval na románskou literaturu, kořeny jeho zájmu o ni vzešly z ročního pobytu v Itálii (1875-1876), kde Vrchlický působil jako vychovatel a tajemník v hraběcí rodině Montecuccoli-Laderchi. Postupnou proměnu mladého Vrchlického dokládá i korespondence se Sofií Podlipskou, v níž s českou spisovatelkou diskutuje o literatuře, o svých básních a rovněž nastiňuje svůj životní básnický plán. Sám Vrchlický přitom retrospektivně reflektoval své „italské“ období jako moment katarze od melancholického tónu svých prvních sbírek a jako období, které ho díky zkušenosti $s$ velkou zahraniční literaturou inspirovalo $\mathrm{k}$ překladu klasických děl, především Dantovy Božské komedie či Osvobozeného Jeruzaléma Torquatta Tassa. V následujících třiceti letech se Vrchlický zaměřil na zpřístupnění co nejširšího výběru zahraniční produkce českému čtenáři, a to bud’ formou překladu klasických děl či ucelených sbírek, nebo formou antologií soudobých básníků, kteří by jinak v českém prostředí zůstali neznámí.

Překladatelská metoda Jaroslava Vrchlického spočívala v maximálním možném uchování formální stránky uměleckého díla, a to i za cenu toho, že se při překládání odchýlil od původního obsahu. Za tento způsob překládání se stal v polovině 90. let Vrchlický terčem dobové kritiky. ${ }^{1} \mathrm{~V}$ monografii České teorie překladu (1957) se sporům Vrchlického a mladší generace věnoval Jiří Levý, který při periodizaci překladatelských teorií vymezil Vrchlického proti Josefu Václavu Sládkovi, jenž dával oproti striktnímu a až parnasistnímu dodržování formy překládaného díla přednost jeho obsahové stránce. Sládek a Vrchlický představují spíše než dva způsoby dobového překládání dva mezní póly s odlišným cílem: zatímco Vrchlický se svými překlady pokoušel pro českou literaturu

1) Kritika překladatelské metody Jaroslava Vrchlického v druhé polovině 90 . let byla vedena zástupci nastupující České moderny, kteří se pokoušeli vymezit proti svým předchůdcům. V souvislosti s překladatelskou činností zdůrazňovali především zachování významu a stylistické individuality originálu (LEVÝ 1996: 187), a to i za cenu obětování formy při překladu prózou, což Jaroslav Vrchlický nepovažoval za umění. Mezi hlavní Vrchlického kritiky patřili v tomto období F. X. Šalda, Jiří Karásek ze Lvovic a Tomáš Garrigue Masaryk. 
zprostředkovat cizojazyčnou literaturu, Sládek užíval překladatelskou činnost k připravení cesty „pro pochopení děl vlastní české literatury“ (LEVÝ 1996: 182). U Sládka Levý taktéž vyzvedl orientaci na ruskou, anglosaskou a severskou kulturu oproti Vrchlického zájmu o románské literatury. Ve vztahu k překládaným skladbám se Levý rovněž vymezil proti Vrchlického univerzálnosti a zdůrazňoval, že úroveň jeho překladů úzce souvisela s tím, do jaké míry mu byla překládaná poezie blízká. Na kritické postoje Jiřího Levého navázala v 60 . letech Ludmila Lantová ve studii Dílo Jaroslava Vrchlického v kritických bojích devadesátých let (1964), která se však zaměřila spíše na dobovou kritiku Vrchlického ze strany Jiřího Karáska ze Lvovic a F. X. Šaldy.

Proti přístupu Levého a Lantové se vymezil ve stati F. X. Šalda a Jaroslav Vrchlický (1967) Oldřich Králík, který rozdělil kritické ohlasy na Vrchlického překladatelskou činnost do dvou kategorií: dobové reakce nastupující generace a pozdější kritické ohlasy. V kontextu kritiky 90. let Králík poukázal především na dobovou potřebu vymezit se proti jednostranně zaměřenému způsobu překládání, který vycházel z postojů České moderny, jež spojovala Vrchlického $s$ akademismem a viděla v něm „úhlavního nepřítele moderních snah“ (KRÁLÍK 1967: 4). Ačkoliv Králík ve své stati přednostně komentoval Šaldovu kritickou recepci Vrchlického překladů, věnoval se v úvodních pasážích i reflexi a kritice Vrchlického pozdějších kritiků, především Jiřího Levého a Ludmily Lantové. U obou literárních vědců přitom kritizoval často černobílé soudy: u Levého např́klad odmítl konfrontaci překladatelské metody Sládka a Vrchlického či spojování Vrchlického s „únavným verbalismem“ (KRÁLÍK 1967: 6), v případě studie Ludmily Lantové poukázal na její přebírání soudů Jiřího Karáska ze Lvovic a jejich modifikaci pro vlastní potřeby.

V návaznosti na naznačené linie kritických ohlasů na Vrchlického překladatelskou činnost zmíníme v předkládané studii nejprve vybrané aspekty související s Vrchlického překladatelskou činností a následně přiblížíme, jakým způsobem byla překladatelskou činností ovlivněna jeho původní tvorba. Vzhledem k šiři Vrchlického zájmu se zaměříme na způsoby uchopení biblického příběhu o stětí Jana Křtitele, který se těšil v druhé polovině 19. století v evropském kontextu velké oblibě. 


\section{Jaroslav Vrchlický a překlady}

Zájem Jaroslava Vrchlického o cizí literatury vzbudil již před pobytem v Itálii jeho strýc Antonín Kolář, farář v Ovčárech u Kolína, u kterého spolu se svým bratrem Bedřichem Vrchlický vyrůstal. O blízkém vztahu Jaroslava Vrchlického a jeho strýce mimo jiné svědčí korespondence $z$ dob pobytu $v$ Itálii, kde $s$ ním často diskutoval o literatuře a o svých plánech. Již na univerzitě se Vrchlický zaměřil na studium filozofie, historie a románských jazyků, což se výrazně odrazilo v jeho překladatelské činnosti. Ačkoli Vrchlický překládal především z románských jazyků (francouzštinu, italštinu a španělštinu), nalezneme v jeho tvorbě překlady i z angličtiny, polštiny a dalších jazyků.

Překladatelská činnost Jaroslava Vrchlického byla zaměřena dvěma směry. První okruh jeho zájmů směřoval ke zprostředkování nejnovější románské literatury, kterou představoval českému čtenáři formou antologií. Řídil se přitom základními dvěma tezemi: „podati co možná nejvíc a podati rovněž věci co nejvíce karakteristické pro dobu i pro autora" (VRCHLICKÝ 1877). Již roku 1877 publikoval první výběr z francouzské literatury (Poesie francouzská nové doby), v němž představil vybrané básně celkem 44 soudobých autorů, mezi nimi například Théodora de Banville, Charlese Baudelaira, Francoise Coppéa, Théophila Gautiera, Victora Huga, Leconta de Lisle, Alfreda Musseta, Gérarda Nervala či Alfreda de Vigny, tedy napřič uměleckými směry posledních padesáti let. Podobným způsobem Vrchlický postupoval i v dalších antologiích, například v Básnických profilech francouzských (1887) či v Moderních básnících francouzských (1893), v nichž uvedený výběr básníků doplnil i stručným vhledem do soudobé francouzské poezie. Vedle výběrových antologií Vrchlický překládal i klasická díla světové literatury, mezi nimi například Fausta Johanna Wolfganga Goetha, Zuřivého Rolanda Ludovica Ariosta, Dantovu Božskou komedii či vybrané sonety Williama Shakespeara a výběry z Byrona, Dumase, Huga či Baudelaira (ve spolupráci s Jaroslavem Gollem).

Rozsáhlá překladatelská činnost významně ovlivnila i Vrchlického původní tvorbu, kdy se inspiroval nejenom v cizích námětech, ale i v cizích formách, za což mu byl soudobými českými literárními kruhy vytýkán eklekticismus. Záměrem Vrchlického však bylo naopak přiblížit touto formou české literatuře dobové zahraniční tendence a formy, které by mohly inspirovat českou literaturu a pozvednout ji na úroveň velkých literatur. K problematice eklekticismu se mimo jiné vyjádřil i v předmluvě $\mathrm{k}$ Moderním básníkům francouzským, kde vyzvedl, že i zahraniční literatury užívají tyto postupy: „Většina i velkých a silných 
talentů podléhá vlivům ciziny i užších kruhů měrou přímo úžasnou. [...] Eklekticismus vládne na celé čáře“ (VRCHLICKÝ 1893: II).

Vlivy cizích námětů se ve Vrchlického díle projevovaly různými způsoby. V některých případech Vrchlický původní příběhy přejímal, v jiných si látku přizpůsoboval vlastním potřebám. Tímto způsobem například postupoval při psaní mystéria Eloa, kdy jeho skladba navazovala na původní báseň Alfreda de Vigny z roku 1823 a domýšlela Eloin příběh.

Ve zbylé části studie budeme sledovat, jakým způsobem byla v díle Jaroslava Vrchlického prezentována Salome a příběh o stětí Jana Křtitele a čím byla její reprezentace ovlivněna v kontextu Vrchlického překladatelské činnosti.

\section{Salome a příběh o stětí Jana Křtitele: tradice a 19. století}

Příběh o stětí Jana Křtitele se těšil v druhé polovině 19. století značné popularitě. Do českého kontextu se rozšířil především díky oblíbenosti v západoevropské kultuře, kde byly oslavovány jeho ženské protagonistky.

První informace o mučednické smrti Jana Křtitele jsou uvedeny v synoptických evangeliích. Jan Křtitel vystupoval proti nemanželskému poměru tetrarchy Heroda Antipy s Herodiadou, manželkou jeho nevlastního bratra Filipa. Za svou kritiku byl Jan uvězněn v pevnosti Machairús. V den Herodových narozenin před tetrarchou zatančila Herodiadina dcera Salome a Herodes jí slíbil splnit jakékoli přání. Na radu matky požádala Salome o Janovu hlavu. Příběh o Janově mučednické smrti byl podobně jako osudy dalších křestanských světců tradován v legendách a homiletických textech, ${ }^{2}$ které se při Janově popisu zaměřovaly na jeho působení a na kritiku hříchů Heroda a Herodiady.

Do umění začal příběh pronikat $v$ období renesance, kdy se stal námětem řady italských a zaalpských malířských děl. ${ }^{3}$ Nejčastěji byl př́běh o stětí znázorněn

2) Vedle teologicky laděné literatury byl př́iběh o stětí Jana Křtitele líčen již od křestanského starověku v dílech dobových historiků. Mezi první prameny tohoto typu, ze kterých legendy a homiletické texty čerpaly dobový kontext, patří např́klad Židovské starožitnosti Josepha Flavia nebo Eusebiovy Církevni dějiny. Popis příběhu o Janově stětí je zaměřen především na vylíčení složité politické situace, ve které se Herodes ocitl po vyhnání své první manželky, dcery arabského krále, popisu Herodovy hostiny a tanci Salome je věnováno minimum prostoru (Salome je přitom vykládána jako postava zcela marginální).

3) Mezi nejznámější vyobrazení př́běhu o stětí Jana Křtitele patří v rámci italské renesance např́iklad fresky od Giotta, Fra Fillipa Lippiho či obraz Benozza Gozzoliho, které zachycují v několika sekvencích tanec Salome před Herodem a Janovu smrt. V Zaalpí byl př́běh o stětí Jana Křtitele často zakomponován do oltářních obrazů, které byly bud’ zaměřeny na významné momenty Janova života (narození, křest Ježǐše Krista, smrt), nebo byl Jan doplněn zobrazením smrti Ježíše a Krista a dalšího vybraného mučedníka. V těchto podobách zobrazili příběh 
formou piktoriálního narativu, ${ }^{4}$ tedy kombinací více scén příběhu v rámci jednoho obrazu. Centrálním výjevem býval tanec Salome před Herodem, který doprovázelo zobrazení Janova stětí nebo prezentace jeho hlavy před hosty na Herodově hostině. $\mathrm{V}$ barokním umění došlo $\mathrm{k}$ postupné redukci zobrazovaného př́iběhu na jednu klíčovou scénu, která implikovala zbytek příběhu. Zároveň došlo ke změně interpretace Salome, kdy se na základě směřování jejího pohledu vymezily tři základní způsoby její charakteristiky: v prvním případě Salome sledovala Janovu hlavu na míse, čímž vyjadřovala svůj souhlas s Janovou smrtí. $\mathrm{V}$ opačném případě se Salome od hlavy odvracela a zdůrazňovala svůj nesouhlas. Poslední varianta, Salome en face, navazovala na první variantu zobrazení (Salome sledující hlavu Jana Křtitele) a umocňovala ji: Salome diváka „vyzývala“ ke kritice a zdůrazňovala svůj aktivní podíl na Janově smrti.

$\mathrm{Na}$ divergentní pojetí Salome ve výtvarném umění navázala v 19. století proměna její literární reprezentace. Jako exemplární příklad hříšné ženy, která se stává kvůli lásce společenským psancem, ji použili již v polovině 19. století romantičtí autoři, například Heinrich Heine v satirickém eposu Atta Troll (1843) či Eugéne Sue v románu Věčný Žid (1844-45). Významný nárůst zájmu o příběh o stětí Jana Křtitele můžeme sledovat od 70. let, kdy se Salome (či Herodias) objevovala nejprve $\mathrm{v}$ dílech francouzských parnasistů, a následně pronikla jako jeden z často aktualizovaných námětů do děl západoevropských symbolistů a dekadentů. V kontextu francouzského umění byla příběhu o stětí Jana Křtitele věnována velká pozornost $\mathrm{v}$ dílech $\mathrm{z}$ let 1871-1884. V tomto období vzniklo torzo zamýšlené skladby Herodias (1871) Stéphana Mallarméa, Flaubertova povídka Herodias (1877) a slavné obrazy Gustava Moreaua, které v nadčasovém zasazení zobrazují Salome tančící před Herodem. Právě obrazy Zjevení a Salome tančicí prè Herodem se staly předmětem subjektivní ekfráze v románu Naruby (1884), v němž Joris Karl Huysmans z perspektivy dekadentního dandyho des Esseintese reflektuje soudobé umění a společnost. Výčet kanonických děl,

o stětí Jana Křtitele např́ílad Rogier van der Weyden či Hans Memling. Po vzoru italské renesance Salome v Zaalpí opakovaně ztvárnil např́klad Lucas Cranach Starší, jehož Salome zároveň reflektuje soudobou regionální módu.

4) Základní rozlišení zobrazovacích stylů, z něhož vycházejí piktoriální narativy, představil ve studii $\mathrm{k}$ redakci Vídeňské Genesis rakouský kunsthistorik Franz Wickhoff. Podle množství zobrazovaných scén a opakování postav rozlišoval tři základní styly: styl zvýrazňující (die distinguierende Erzählungsweise), sekvenciální (die kontinuierende Erzählungsweise) a shrnující (die komplettierende Erzählungsweise). Nejstarším z těchto stylů je styl shrnující, který byl uživán již v antickém umění. Podstatou tohoto zobrazení bylo propojení dvou a více scén, ovšem za podmínky, že se v nich žádná postava neopakovala. Pokud se postavy v jednotlivých scénách opakovaly, jednalo se o styl sekvenciální, který užival například Michelangelo a jeho následovníci. Poslední zobrazovací styl se rozvinul v pozdní renesanci a je spojován s portrétním uměním. Základním rysem zvýrazňujícího stylu je vyzdvižení ikonické scény př́iběhu, která zastupuje celý prúběh. Tento styl se postupně prosazoval a od 16. století prakticky nahradil zbývající zobrazovací styly. 
oslavujících v západoevropském umění na konci 19. století Salome, uzavřel na počátku 90. let Oscar Wilde se svou jednoaktovkou Salome (1891), v níž představil subjektivizovanou podobu Salome jako smrtící femme fatale. Zatímco se v symbolistně-dekadentní literatuře při reprezentaci Salome postupně rozvíjela čtyři osudová gesta, v nichž tanečnice dominovala nad muži, ${ }^{5}$ souběžně se vyvíjela linie, která parodizovala či jinak upravovala původní příběh (například Salome Julese Laforgua nebo stejnojmenná báseň Guillauma Apollinaira).

V české literatuře se novodobé aktualizace příběhu o stětí Jana Křtitele poprvé objevily v polovině 50. let, kdy Josef Václav Frič publikoval v almanachu Lada Nióla skladbu Život sváteční. V odkazech na příběh o Janově stětí se přitom přímo inspiroval eposem Atta Troll Heinricha Heina. Další aktualizace př́iběhu byly v českém kontextu ovlivněny především francouzskou literaturou a jejími překlady, o které se zásadně zasloužil Jaroslav Vrchlický a jeho generace. ${ }^{6}$ Na přelomu století se vliv západoevropské dekadence promítl i do aktualizace Salome v díle S. K. Neumanna, Karla Hlaváčka či Jiřího Karáska ze Lvovic, přičemž skladby posledních dvou jmenovaných přistupovaly $\mathrm{k}$ námětu $\mathrm{z}$ nové perspektivy: Hlaváčkova Salome netančí, Karáskova naopak ve svém pokročilém věku během tance omládne, a když ani takto nevyhraje přízeň milovaného muže, pošle mu v osudovém gestu svou utatou hlavu na míse jako dar.

Po první světové válce zájem o příběh o stětí Jana Křtitele v evropském kontextu postupně odezněl, což se stalo $v$ důsledku kompletní změny společnosti a pod vlivem nových problémů, na něž umění reagovalo. V návaznosti na reprezentace Salome v druhé polovině 19. století byl příběh i nadále aktualizován (především v kinematografii, která se inspirovala zejména Wildeovou Salome ${ }^{7}$ ), jeho zastoupení je však dodnes spíše marginální a nedosahuje takového význa$\mathrm{mu}$ jako $\mathrm{v}$ předminulém století.

5) Oproti starší literatuře, ve které byla Salome přednostně spojena s tancem před Herodem, se v symbolistně-dekadentní literatuře postupně prosadila i další osudová gesta, která manifestovala její vítězství. Jednalo se o moment žádosti o hlavu Jana Křtitele (a její následné odmítnutí), polibek na Janovy mrtvé rty a Salomeina smrt.

6) V předkládané studii navazuji a rozpracovávám svůj předchozí článek, který byl publikován v České literatuře (4/2014) pod názvem Obraz Salome v české literatuře druhé poloviny 19. století, jenž byl zaměřen nejen na práce Jaroslava Vrchlického, ale i na další způsoby reprezentace Salome v českém literárním kontextu.

7) Filmy na motivy Wildeovy hry či obecně zpracovávající prríběh o stětí Jana Křtitele začaly vznikat ve 20 . letech 20. století. Mezi nejslavnější zpracování patří němý filmy Salome z roku 1923 (režie Charles Bryant) v hlavní roli s Allou Nazimovou či Salome v režii Williama Dieterle z roku 1953 (v hlavní roli s Ritou Hayworth). Od literární předlohy se výrazně odlišuje film Kena Russela Salome’s Last Dance (1988) v hlavní roli s Imogen Millais-Scott, který karikuje Wildeovo drama: v první rovině příběhu je inscenováno Wildeovo drama, kde jednotlivé postavy hrají prostitutky, v druhé rovině inscenaci sleduje a komentuje Oscar Wilde. Mezi nejnovější filmové adaptace na motivy příběhu o stětí Jana Křtitele patři film Wilde Salome (2011), který zrežíroval Al Pacino a v němž vystoupila v hlavní roli Salome Jessica Chastain. Al Pacinova adaptace sestává ze tř́i linií a vedle inscenace původní hry představuje i přípravy natáčení a vlastní reflexi života a díla Oscara Wildea. 


\section{Salome v díle Jaroslava Vrchlického}

Oblíbenost Salome a příběhu o stětí Jana Křtitele se na konci 19. století odrazila i v rozsáhlé tvorbě Jaroslava Vrchlického. Zájem o tento biblický příběh korespondoval s jeho snahou obsáhnout v připravovaném básnickém cyklu evoluci člověka, jak naznačil již v dopisu z Itálie svému strýci Antonínu Kolářovi na konci srpna roku 1875: „V̌̌echny mé sbírky půjdou k jednomu cíli. Chci v zrcadle poesie ukázati člověka v celém jeho rozvoji. Nebude ovšem úplné soustavy v tom: tento člověk, jehož ukazuji, bude vždy pod různou maskou více méně já, ale to hlavní, on zůstane člověkem, on bude považovati historii, filosofii, dogma i legendu, náboženství i pověru za jediný řetěz svého rozvoje, za jediné velké ohniště, z něhož tkají se neznámé paprsky kol čela neznámého božství. Patrně bude ethos jádrem této veliké lyricko-epické symfonie, ale ethos pod úhlem nejširším, kam by se vtěsnati mohl Dante se svou scholastikou i Byron se svým pessimismem. Ne jednotlivé stránky člověka (Faust, Manfred), ale člověka celého, ne jednu dobu, ale věky, ne jeden národ, ale lidstvo“ (FRÍDA 1931: 104).

Zamýšlený cyklus „Zlomků epopeje“ začal vznikat na konci 70. let a zahrnoval sbírky zpracovávající náměty od nejstarších dějin lidstva až po Vrchlického současnost, jeho součástí byly i rozsáhlejší epické skladby. V polovině 80 . let se v jedné z nich poprvé objevila jako epizodická postava i Herodiada z př́běhu o stětí Jana Křtitele.

\section{Twardowski}

Skladba Twardowski byla vydána v nakladatelství Františka Šimáčka na začátku roku 1885. ${ }^{8}$ Námětově vycházela z polské variace faustovské látky. Hlavní postavou skladby je mladý polský šlechtic Twardowski, který je po narození proklet svým otcem a je celý život pronásledován d'áblem. Zatímco v dětství d’ábel chlapce pouze pozoruje, během studií se stane jeho společníkem, zasvětí ho do tajů magie a pokouší se ho svést $\mathrm{k}$ hříchu. Twardowski nejprve jeho vábení

8) Publikování skladby se neobešlo bez problémů. I když části básně vycházely na pokračování v časopise Lumír již v první polovině 80. let, náklad výtisků byl zkonfiskován a na Vrchlického a Šimáčka byla podána žaloba. Jejím předmětem byly barvité popisy nástrah, které kladl dábel Twardowskému (svedení děvčete, osvětlení Twardowského původu atd.). Mezi pasážemi, které byly označené za nevhodné, byla i kapitola Noční zábavy. Konkrétně u této kapitoly bylo vyzdviženo, že se jednalo o postavy, které jsou v literatuře běžně užívány pro příměr, a že byly použity jako prostředek, který měl poukázat na to, čím se d'ábel pokoušel zaslepit Twardowského. V dubnu téhož roku byl vynesen rozsudek, který zamítal nařčení z nemravnosti a náklad byl vrácen nakladateli Františku Šimáčkovi. V plném znění byl rozsudek otištěn v časopise Lumír 20. 4. 1885. 
podléhá, následně se ale zděsí a pokouší se napravit. V momentu, kdy se dábel chystá zmocnit jeho duše, se Twardowski modlí k Panně Marii a je zachráněn: nejprve se ocitá mimo časoprostor, po letech je mu ale odpuštěno a nachází klid.

Příběh o stětí Jana Křtitele je tematizován v kapitole Noční zábavy, kdy Twardowského navštěvují s příslibem zjevení pravdy Scholastika s Mystikou. Po vzájemné konfrontaci ale zmizí a Twardowski se pokouší dobrat pravdy skrze pomoc d’ábla. Ten mu však poradí, aby se prozatím spokojil se ženou, a slibuje, že mu vyvolá přelud, jaký jen bude chtít. Twardowski mu na to popíše ženu, po jaké touží:

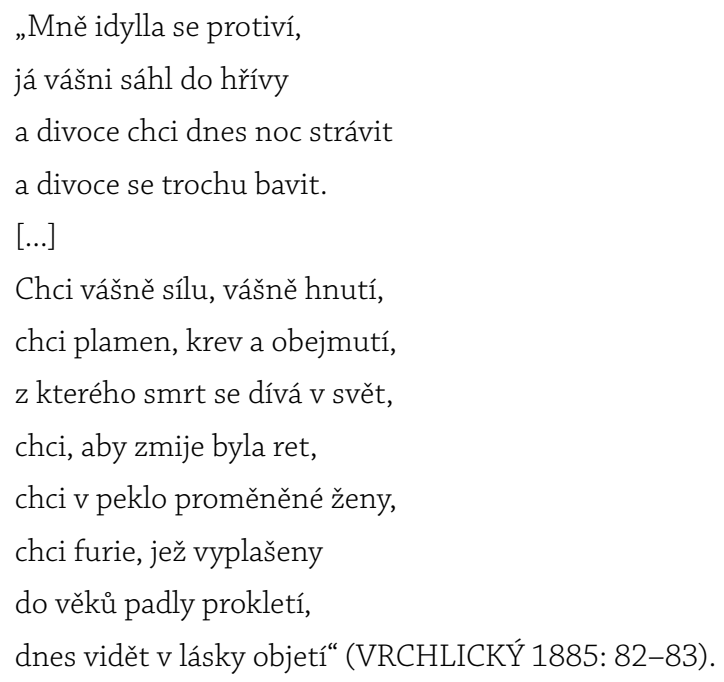

Na toto zadání vyvolává d'ábel Twardowskému postupně přízraky Semiramidy, Betsabe, Lesbie, Herodiady a Evy. Každá žena shrnuje před šlechticem svůj životní příběh, nejvíce přitom Twardowského okouzlí Herodiada, která své negativní ženství komentuje v kontextu příběhu o stětí Jana Křtitele, kdy popisuje neúspěšné svádění Jana a následný tanec před Herodem:

„Jej lákala a svlékala své šaty

a spouštěla vlas vlnitý a zlatý,

leč vždycky odvrátil se vážný, tich,

na vzdechy mé děl drsně: ,Ty jsi hřích!‘

Vše nadarmo. Vztek rozpálil mne v muce,

já ku králi šla a spínajíc ruce 
jsem vztek svůj vlila v tance běsný rej,

a při tom stále, stále zřela jej.

,Co poroučíš,' děl král, ,to má se státi,

chci, co si zvolíš, v obět tobě dáti.

Já chtěla mít své lásky mstitele

a řekla chladně: ,Hlavu Křtitele““ (VRCHLICKÝ 1885: 96).

Způsobem Herodiadiny sebeprezentace navázal Jaroslav Vrchlický na její reprezentaci v polovině 19 . století v romantické literatuře západní Evropy, a to v díle Eugèna Sue či Heinricha Heina. Oba autoři přitom - stejně jako Vrchlický - propojují Herodiadu a Salome a vytváří tak jedinou ženskou postavu, která je zatížena hlavní vinou za Janovu smrt. Na rozdíl od romantické literatury Vrchlický představuje Herodiadu v souladu s dobovou literaturou jako osudovou ženu, zatímco ji Heine a Sue propojují s motivem věčného trestu a nechávají ji poslední staletí bloudit prokletou světem.

Vedle zobrazení Herodiady jako osudové ženy je její reprezentace u Vrchlického ovlivněna i jeho rozsáhlou překladatelskou činností, v níž se autor inspiroval při výběru dalších ženských postav, které se zjevují před Twardowským. Hlavním inspiračním zdrojem mu přitom byl pátý zpěv prvního dílu Dantovy Božské komedie,${ }^{9}$ kde je popisován druhý okruh pekla, v němž jsou Mínóem střeženy duše těch, kteří zhřešili tělesnými žádostmi. Poprvé použil Vrchlický podobný výběr postav jako Dante již ve skladbě Eloa, kterou dokončil za svého ročního pobytu v Itálii a o níž v korespondenci diskutoval se Sofií Podlipskou, svým bratrem a strýcem. ${ }^{10}$

9) „Dím proto: ,Mistře, kdo jsou, dej mi zprávu, / Jež bičuje tak vichr pekla luhem?'// A na to on: ,Ta první z toho davu, / O níž chceš zvědět, mnohým rodům vládla, / Nad mnohé země svou roznesla slávu. // Leč do zločinů chlípnosti tak padla, / Že by zakryla těžkou svoji vinu, / Bez trestu chlípnost do zákonů kladla. // Tot Semiramis jak se čte, jež Ninu / Trůn vlády, jeho žena, uloupila / V zemích, kde Sultán svou má domovinu. // Ta druhá, ta se z lásky usmrtila, / Slib zrušivši popelu Sicheovu, / Ta třetí chlípná Kleopatra byla. // Pak Helena, jíž rodu Priamovu / Tak mnoho bědy vzešlo, Achill za ní, / jenž s láskou válčil až ku svému rovu“ “(ALIGHIERI 1879: 27).

10) Postavy, které doprovázejí Elou, jsou uvedeny v poznámce básně: „Hluboké ticho. $Z$ různých stran vystupují nově řady stínů. Nejvíce ženy, hřešivší vášnivou láskou a chlipností: Semiramis, Kleopatra, Messalina, Hero, Sapfo, Poppea a jiné“ (VRCHLICKÝ 1879: 216). 


\section{Sonety samotáře}

Souběžně s Twardowským byla roku 1885 publikována sbírka Sonety samotáře, která však není na rozdíl od Twardowského součástí cyklu „Zlomky epopeje“, ale patří $\mathrm{k}$ Vrchlického subjektivní lyrice. Sbírka mimo jiné reflektuje štastné období Vrchlického manželství, kdy je jeho manželce Ludmile (dceři Sofie Podlipské) věnována řada básní. Po formální stránce byly ve sbírce obsaženy sonety, které byly u Jaroslava Vrchlického charakteristické svou dvojdílností, kdy první strofy reprodukovaly určitý jev a závěrečných šest veršů (či závěrečné trojverší) hledalo analogii v básníkově vnitřním životě, či vyjadřovalo jeho postoje, úvahy a soudy (PEŠAT 1961: 311). ${ }^{11}$

Vedle subjektivní lyriky jsou ve sbírce obsaženy i sonety oslavující umění a umělce od antiky až po Vrchlického současníky. V cyklu Nové masky a profily, který je dedikován Juliu Zeyerovi, věnoval Vrchlický pozornost i slavnému francouzskému symbolistnímu malíři Gustavu Moreauovi. S opakujícím se citátem „odi profanum vulgus“ (nenávidím lůzu) ${ }^{12}$ Vrchlický odkazuje k snovému zaměření Moreauových obrazů, v jejichž středu zaujímal významné postavení cyklus tematizující příběh o stětí Jana Křtitele. Odkazu k tomuto příběhu je věnována druhá strofa básně: „Hle, Salomé, žár vášně v oku vlahém, / před Heródem jak křepčí svůj rej smělý! / Jak jaro básnil Sandro Bittocelli, / svět začíná ti za skutečna prahem" (VRCHLICKÝ 1885: 131). Vrchlický těmito verši odkazuje ke slavným obrazům Salome tančici před Herodem a Zjevení, které Moreau představil na pařižském Salonu roku 1876. Reprezentaci Salome na obrazech je podřízena i její charakteristika, kterou Vrchlický shrnul do slov „žár vášně v oku vlahém“ (IBID.), jež odkazuje k romanticko-symbolistní podobě, v jaké ji Gustave Moreau zachytil. Srovnáme-li charakteristiku hlavní ženské postavy s její podobou v současně vydané epické skladbě Twardowski, je ještě více patrné, nakolik byl Vrchlický ovlivněn svou činností v oblasti překládání či cizími uměleckými díly. Ponecháme-li stranou, že v případě Twardowského splývá Herodiada a Salome v jedinou postavu, Salome v básni Gustave Moreau ztrácí na úkor symbolismu svou osudovost a veskrze negativní atributy osudové ženy, $\mathrm{s}$ jakými byla představena $\mathrm{v}$ Twardowském. V intencích citátu „odi profanum vulgus“ je Salome spolu s dalšími díly Gustava Moreaua reflektována i v závěreč-

11) Podle Pešata Vrchlický využívá tohoto kontrastu nejčastěji u historických témat, kdy tímto způsobem konfrontuje minulost a př́tomnost, což mu umožňuje vyslovit kritiku přítomnosti.

12) Citát „odi profanum vulgus“ (cele „odi profanum vulgus et arceo“ - „nenávidím lůzu a straním se jí“) pochází z díla římského básníka Quinta Horatia Flacca (Carmina III, 1,1). 
ném trojverší, které odkazuje k nadčasovosti Moreauových děl: „I chápu, necháš dav, jenž kol se žene, / tvá duše do hvězd upřeně se dívá / $\mathrm{k}$ rtům věčné sfingy křídlo nakloněné" (VRCHLICKÝ 1885: 131).

Podobně jako v Sonetech samotáře reflektoval Vrchlický umění i v navazujících sbírkách Nové sonety samotáre (1891) a Poslední sonety samotáře (1896). Zatímco v Sonetech samotáře Vrchlický přistoupil k umělcům a jejich obrazům především ze subjektivní perspektivy, v navazujících sbírkách zvolil ekfrázi, která je zakončena subjektivní reflexí zobrazované scény. Postavy z příběhu o stětí Jana Křtitele jsou tímto způsobem reflektovány v obou sbírkách: v Nových sonetech samotáre je popisován Tintorettův obraz Narození svatého Jana Křtitele a v Posledních sonetech samotáře je příběh o Janově stětí aktualizován s odkazem na obraz významného českého malíře Beneše Knüpfera v básni Hlava Jana Křtitele.

Báseň Hlava Jana Křtitele tematizuje noc po Herodově hostině, kdy je Herodiadě v ložnici královského páru předána Janova utaatá hlava. První strofy sonetu jsou zaměřeny na popsání atmosféry, do níž přichází kat s prorokovou hlavou. Pro charakteristiku Herodiady je stěžejní část druhé strofy, která popisuje Herodovo chování: „Co se Herodias k ňadrům vládce tlačí / skráň znavenou, pták krotký, jenž jí z ruky“ (VRCHLICKÝ 1896: 85). Herodovo submisivní chování je doplněno předáním Janovy utaté hlavy, čímž je odkazováno na Herodiadinu dominanci, která je vlastní osudovým ženám konce 19. století. Na rozdíl od obou reprezentací z roku 1885 není v básni Hlava Jana Křtitele vyloučeno, že Herodiadě k pomstě na Křtitelovi domohla Salome, pozornost je však soustředěna pouze na Herodiadu a její triumf.

\section{Zlomky epopeje a básně epické}

Po umělecké ekfrázi v sonetech z 90. let se Jaroslav Vrchlický k příběhu o stětí Jana Krrtitele vrátil na přelomu století v epicko-reflexivních skladbách v rámci cyklu „Zlomky epopeje“ ve sbírce Bozi a lidé (1899) a v Třetí knize básní epických (1907).

Sbírka Bozi a lidé shrnovala epickou tvorbu Jaroslava Vrchlického za roky 1891-1899 a stejně jako v ostatních sbírkách z cyklu jsou v ní básně řazeny podle námětů od nejstarších dějin až po Vrchlického současnost. Společným rysem všech básní je střet člověka a boha, z něhož člověk nikdy nemůže vzejít jako vítěz. Variace tohoto konfliktu je námětem i básně Předchưdce, která popisuje vnitřní nejistotu a váhání Jana Křtitele. V básni je z Janovy perspektivy 
nahlíženo jeho dosavadní působení a setkávání se s Ježíšem Kristem, kterého poprvé potkal jako malý chlapec. Předmětem Janových úvah jsou především momenty, kdy nad ním Ježíš vyniká, ale Jan zároveň není schopen jej za to nenávidět a je v životě dál hnán touhou vyrovnat se mu a případně ho i překonat. Své vlastní nedostatečnosti si je Jan vědom zejména $v$ momentech, kdy není schopen vyslovit své myšlenky a uvědomuje si, jak vnímal Ježíše již při setkání v dětství:
„Ted’ pochopil, co v jeho oku čet';
to byla síla, které postrádal,
to byla jistota ve každý boj,
to bylo vítězství $v$ tom boji všem
a všecko takou vlídnou účastí

a láskou spojené, že trnul nad tím.

Ten stačil k tomu, nikoli však on" (VRCHLICKÝ 1899: 183).

Jan se pokouší najít odpověd’ na své životní váhání v poustevnickém životě. Během pobytu v poušti má vidiny Satana, který mu našeptává otázku, kterou si v celé skladbě Jan opakovaně v duchu pokládá: „Proč on a ne ty?“ (VRCHLICKÝ 1899: 186) Jan se tedy vrací z pouště pouze s myšlenkou, že je předchůdcem, ale ničím víc.

Ze zdánlivě bezvýchodné situace pomáhá Janovi Jidáš, před kterým se na břehu řeky Jan Křtitel ukrývá a vyslechne jeho monolog. Jidášův pohled na Ježíše se $\mathrm{v}$ mnohém blíží Janovu rozpoložení, $\mathrm{v}$ závěrečném momentu se však jejich postoje a nazírání vlastního místa zcela liší:

\author{
„Zřejmo, prohrál jsem, \\ on všady první a já poslední, \\ já tolik chtěl, on vždy mne předešel, \\ však předchůdce mu dělat - nebudu. \\ Co dnes se stalo, to mi dostačí. \\ On všady vítězí a vévodí, \\ at mrzáků si láká bědný dav \\ svým divem, nehne mne, však že moh‘ ji, \\ mou Majdalenu hravě obelstít, \\ že nardy vzácnou vásu vylila \\ na jeho nohy, kde já žebrák stál,
}


a nezřen v stínu - to mu neodpustím.

Nač v jeho učenníků vstoup jsem vlek?

By zdeptal mne? Já mohu, co on též.

Jest větším mne? Proč, jak a co chce tím?

Já totéž mohu, tímtéž plám a vru,

chci jak on nejvyšší, proč platí on?

Co jeho sladkost mému odříkání,

co jeho úsměv ranám mojim jest?

$[\ldots]$

On, tesařův syn, oč jsem jeho menší?

Ne, nikdy ne, to nikdy nestrpím!“ (VRCHLICKÝ 1899: 190-191)

Podobnost Jidáše a Jana $\mathrm{v}$ touze po velikosti zastupuje ( $\mathrm{v}$ intencích názvu sbírky) jejich morální odlišnost jako lidí v komparaci s Ježíšem jako zástupcem božského principu. ${ }^{13}$ Vyslechnutím Jidášova názoru na Ježíše dochází Jan kýžené katarze:

„Ted’ v jeho duši teprv zaplál den!

Ted' viděl zřejmě, jaký rozdíl jest

v té ušlechtilé snaze, v které žil,

a v této vášni! Jak moh', couvnul zpět,

a zašel opět v svoji samotu,

byl silnější. V něm snaha, zloba tam.

I přemýšlel a cítil v duši hloubi,

jak blízko též byl tomu Jidáši,

však chápal jasně, oč ted lepším byl,

ač v jádru v kořenu mu příbuzný

svou celou snahou. Ježíš vítěz přec!“ (VRCHLICKÝ 1899: 192)

Dokladem Janova „rozhřešení“ je závěrečná strofa, která sumarizuje další události v jeho životě. Popsáno je jeho uvěznění a následná smrt stětím, kdy

13) Charakterové odlišení Jana a Jidáše ve srovnání s Ježíšem tematicky odpovídá zaměření sbírky. To je zřejmé mimo jiné i při komparaci se starším obrazem Jana Křtitele, jak jej Vrchlický představil ve sbírce Hlasy z pouště (1890). Je-li pro Jana v Předchůdci charakteristické váhání o vlastním poslání, starší verze Křtitele v básni Vstup jej stručně charakterizuje jako klidného a cílevědomého proroka. Předmětem básně pak není psychologizovaná podoba Jana Křtitele, ale jeho využití jako symbolického vůdce, který vytrhává společnost z lhostejnosti. Tomu odpovídá i závěrečné šestiverší sonetu, kdy lyrický subjekt aplikuje Janův př́istup na soudobou společnost a v intencích agitačního zaměření sbírky jej dává za příklad hodný následování. 
je zběžně zmíněna i Salome. V komparaci s rozsáhlými úvahovými pasážemi se pak další události $v$ Janově životě jeví jako marginální a znovu je zdůrazněna důležitost jeho poslání. Tomu odpovídá i stručná zmínka o Salome a okolnostech Janova stětí, kdy je pouze zmíněno, že Jan umírá, aby „chtíč svůj ukojila Salomé“ (VRCHLICKÝ 1899: 192), čímž Vrchlický navazuje na její dobově atraktivní reprezentaci jako osudové ženy.

Poslední reprezentaci Salome představil Jaroslav Vrchlický v Třetí knize básní epických, která byla publikována roku 1907. Vrchlický v ní navázal na své dřívější sbírky epických básní, jež publikoval od druhé poloviny 70. let. Jednalo se přitom především o básně, které nebyly zařazeny do výpravného cyklu „Zlomky epopeje“ (PEŠAT 1961: 297). Již sbírka Epické básně (1876) se vyznačovala pohádkovými a mytologickými náměty, často s nadčasovou platností, které Vrchlický čerpal z evropských literatur. S odstupem více než třicet let od první sbírky se v Třetí knize básní epických odklonil od pohádkového charakteru často milostných básní směrem $\mathrm{k}$ vážnějším tématům, která se $\mathrm{v}$ mnohém blížila námětům epických skladeb v souběžně vydávaném cyklu „Zlomků epopeje“. Do oddílu Miniatury a pastely zařadil mezi básně na motivy z antické mytologie, křestanského starověku a středověku báseň Herodias, která popisuje Herodiadin tanec před Herodem a smrt Jana Křtitele.

První čtyři strofy básně jsou zaměřeny na Herodiadin tanec před Herodem. Tanečnice je již v úvodu druhé sloky přirovnána ke třtině, jež je zmítána v bouři. Ve stejném duchu je popisována i hudba, která doprovází její tanec: „Postava celá třtina / v bouři se chví, / ted' klesá, ruce vzpíná, / hned žhnoucí tvář, hned siná, / skok, sílá lví. // Lká loutna, cymbál výská, / až duní síñ“ (VRCHLICKÝ 1907: 62). Na vstupní popis tance navazuje strofa reflektující zadumané rozpoložení krále, který sedí schoulený na svém trůně. Herodův popis se přitom blíží Huysmansově ekfrázi obrazů Gustava Moreaua v románu Naruby, kde je $\mathrm{v}$ tomto kontextu zdůrazněno vítězství tanečnice nad vladařem. Ve Vrchlického básni je její naznačená dominance nad muži umocněna v závěru tance, který je zakončen vítězným gestem: „Ted’ vzpřímila se třtina, / ruch sálem chví, / co ručka její líná / déšt růží hází z klína / v svém vítězství“ (VRCHLICKÝ 1907: 63). V momentě, kdy Herodiada dotančí, je jí přinesena utatá hlava Jana Křtitele, o kterou si v rozporu s běžným schématem příběhu nemusela ani říct. Opět netradičně ji jako první bere do rukou Herodes a ve verších „vjel hrubou rukou s pychem / do černých kštic" (VRCHLICKÝ 1907: 63) je vyjádřen jeho souhlas s Janovou smrtí. Báseň je zakončena Herodiadiným osudovým gestem: 
symbolickým odmítnutím Janovy hlavy: „Však ona s hlasným smíchem: / „Nechci ji víc!““ (VRCHLICKÝ 1907: 63).

Pro báseň je příznačná koncepce tanečnice, jejíž jméno není ani jednou zmíněno. Vzhledem k titulu můžeme pouze odvodit, že se jednalo o Herodiadu tančící před Herodem a ne o její dceru Salome. Propojením obou postav v tančící Herodiadu a vyzdvižením vášně (či vzteku), se kterým před Herodem tančí, se Vrchlický koncepčně vrátil k podobě, v jaké ji představil již ve skladbě Twardowski $\mathrm{v}$ polovině 80 . let, kde Herodiada mladému šlechtici popisovala své vítězství jako důsledek raněné hrdosti.

Všechny podoby Salome v díle Jaroslava Vrchlického dokládají, jak významně byl Vrchlický v původní tvorbě ovlivněn svou překladatelskou činností a svou orientací na evropskou literaturu. Nejvýrazněji se tyto tendence promítly již do jeho skladby Twardowski (1885), která nejenom aktualizovala původně polskou faustovskou látku, ale do které navíc Vrchlický promítl vlivy překladů italské literatury, především Dantovy Božské komedie. Vrchlického zájem o západoevropský parnasismus byl zřetelný vedle rozsáhlých antologií románské poezie i ve sbírkách sonetů, v nichž vedle dodržování specifické formy využíval i postupů ekfráze, kdy subjektivně reflektoval umělecká díla či jejich části. $V$ případě příběhu o stětí Jana Křtitele tak mimo jiné odkazoval k tradici uměleckého zpracování př́běhu nejen ve Francii, ale i v kontextu českého výtvarného umění druhé poloviny 19. století. Zatímco obě předešlé linie vycházely především z vlivu překladové literatury, v subjektivní reflexi se příběh o stětí objevil i v rámci Vrchlického cyklu „Zlomky epopeje“ a v souběžně vydávaných epických básních. Bylo-li životním cílem Jaroslava Vrchlického vytvoření uvedeného cyklu, je díky básni Předchůdce patrný i jeho subjektivní postoj k Salome. Ten se promítá i do ostatních básní, v nichž je pod vlivem tradicionalistického výkladu př́běhu a romantické podoby Salome tato postava redukována a nahrazena tančící Herodiadou, která zastupuje negativní ženství. Ve všech uvedených básních navíc Vrchlický reflektoval určitý dobově podmíněný pohled na příběh o stětí Jana Křtitele, který dokládá rozmanité podoby, v nichž byl v průběhu 19. století příběh v evropských literaturách aktualizován.

Studie vznikla $v$ rámci Institucionální podpory na dlouhodobý koncepční rozvoj výzkumné organizace - Moravská zemská knihovna v Brně v roce 2017. 
Soňa Šinclová

Podoby Salome v díle Jaroslava Vrchlického

\section{PRAMENY}

ANONYM

1885 „Rozsudek o Twardowském“, Lumír XIII, č. 12, s. 23-24

BIBLE

2009 Bible: překlad 21. století (Praha: Biblion)

ALIGHIERI, Dante

1879 Božská komedie, dỉl 1 (Praha: Jaroslav Vrchlický)

APOLLINAIRE, Guillaume

1996 „Salome“, in Alkoholy (Praha: Odeon), s. 61

EUSEBIOS Z CAESAREJE

1988 Církevní dějiny (V Praze: Ústřední církevní nakladatelství)

FLAUBERT, Gustave

1975 „Herodias“, in Tři povídky (Praha: Odeon), s. 111-161

FLAVIUS, Josephus

1900 Jüdische Alterthümer (Köln am Rhein: Drück und Verlag von J. P. Bachem)

FRIČ, Josef Václav

1855 „Život sváteční“, in Lada Nióla (Praha: Josef Václav Frič), s. 101-169

FRÍDA, Bedřich

1931 Mladá léta Jaroslava Vrchlického v zrcadle dopisů, jež psal svému strýci a bratrovi (Praha: Společnost J.

Vrchlického)

HEINE, Heinrich

1874 Atta Troll: sen letní noci (V Roudnici: Nákladem kněhkupectví A. Mareše)

HLAVÁČEK, Karel

1930 „Herodias“, in Básně (Praha: Kvasnička a Hampl), s. 102-104

HUYSMANS, Joris Karl

1993 Naruby (Praha: Sdružení na podporu vydávání časopisů)

KARÁSEK, Jiří ze Lvovic

1991 „Smrt Salomina“, in Gotická duše a jiné prózy (Praha: Vyšehrad), s. 85-89

LAFORGUE, Jules

1934 Legendární morality (Praha: R. Škeřík) 
MALLARMÉ, Stéphane

1996 Faunovo odpoledne a jiné básně (Praha: Svoboda)

NEUMANN, Stanislav Kostka

1903 „Salome“, in Sen o zástupu zoufajících (Praha: Moderní revue), s. 22-23

SUE, Eugène

1915 Věčný Žid 1-4 (Praha: Alois Hynek)

ŠALDA, František, Xaver

1913 Duše a dílo: podobizny a medailony (V Praze: Unie)

VRCHLICKÝ, Jaroslav

1875 Z hlubin (Praha: J. Otto)

1877 Poesie francouzská nové doby (Praha: Ed. Grégr)

1879 Mýty 2 (Praha: J. Otto)

1885 Twardowski: báseň (Praha: František Šimáček)

1885 Sonety samotáre (Praha: J. Otto)

1890 Hlasy z pouště (Praha: J. Otto)

1891 Nové sonety samotáre (Praha: J. Otto)

1893 Moderní básníci francouzští (Praha: Jos. R. Vilímek)

1896 Poslední sonety samotáre (Praha: J. Otto)

1897 Nové studie a podobizny (Praha: F. Šimáček)

1899 Bozi a lidé (Praha: J. Otto)

1907 Třetí kniha básní epických (Praha: Nákladem J. Otty)

1912 Nové básně epické (Praha: Nákladem J. Otty)

1913 Epické básně (Praha: Nákladem J. Otty)

VRCHLICKÝ, Jaroslav - F. X. ŠALDA - Václav BRTNÍK a Sofie PODLIPSKÁ

1917 Dopisy Jaroslava Vrchlického se Sofí Podlipskou z let 1875-1876 (Praha: F. Borový)

WILDE, Oscar

1959 Salome (Praha: Orbis)

\section{DALŠí PRAMENY}

Salome [film]. Režie Charles Bryant. USA, 1923.

Salome [film]. Režie William Dieterle. USA, 1953.

Salome's Last Dance [film]. Režie Ken Russel. USA, 1988.

Wilde Salome [film]. Režie Al Pacino. USA, 2011. 


\section{LITERATURA}

KRÁLÍK, Oldřich

1967 F. X. Šalda a Jaroslav Vrchlický: př́spěvek k velkému tématu (Olomouc: Vzorná okresní knihovna)

LANTOVÁ, Ludmila 1964 „Dílo Jaroslava Vrchlického v kritických bojích devadesátých let“, Česká literatura, č. 3, s. 353-376

(1)

LEVÝ, Jiří - Jiří HONZÍK

1996 České teorie překladu: Vývoj prekladatelských teorií a metod v české literatuře, sv. 1, 2 (Praha: Ivo Železný)

PEŠAT, Zdeněk

1961 „Jaroslav Vrchlický“, in Dějiny české literatury III. (Praha: ÚČL ČSAV), s. 294-323

ŠINCLOVÁ, Soňa

2014 „Obraz Salome v české literatuře druhé poloviny 19. století“, Česká literatura, č. 4, s. 549-571

WICKHOFF, Franz a Wilhelm von HARTEL

1895 Die Wiener Genesis (Prag: F. Tempsky)

PhDr. Soňa Šinclová, sona.sinclova@mzk.cz, Moravská zemská knihovna, Brno, Česká republika / The Moravian Library, Brno, Czech Republic 